\title{
Insulin-like Growth Factor I Stimulates Lipid Oxidation, Reduces Protein Oxidation, and Enhances Insulin Sensitivity in Humans
}

\author{
Mehboob A. Hussain, ${ }^{*}$ Ole Schmitz, ${ }^{\star}$ Annette Mengel, ${ }^{\star}$ Annamarie Keller, * \\ Jens. S. Christiansen, ${ }^{\star}$ Jürgen Zapf, * and E. Rudolf Froesch ${ }^{\star}$ \\ * Division of Endocrinology and Metabolism, Department of Internal Medicine, University Hospital, \\ 8091 Zürich, Switzerland; and ${ }^{\ddagger}$ Department of Medicine II, 8000 Aarhus, Denmark
}

\begin{abstract}
To elucidate the effects of insulin-like growth factor I (IGF-I) on fuel oxidation and insulin sensitivity, eight healthy subjects were treated with saline and recombinant human IGF-I (10 $\mu \mathrm{g} / \mathrm{kg} \cdot \mathrm{h}$ ) during $5 \mathrm{~d}$ in a crossover, randomized fashion, while receiving an isocaloric diet $(30 \mathrm{kcal} / \mathrm{kg} \cdot \mathrm{d})$ throughout the study period. On the third and fourth treatment days, respectively, an L-arginine stimulation test and an intravenous glucose tolerance test were performed. A euglycemic, hyperinsulinemic clamp combined with indirect calorimetry and a glucose tracer infusion were performed on the fifth treatment day. IGF-I treatment led to reduced fasting and stimulated (glucose and / or L-arginine) insulin and growth hormone secretion. Basal and stimulated glucagon secretion remained unchanged. Intravenous glucose tolerance was unaltered despite reduced insulin secretion. Resting energy expenditure and lipid oxidation were both elevated, while protein oxidation was reduced, and glucose turnover rates were unaltered on the fifth treatment day with IGF-I as compared to the control period. Enhanced lipolysis was reflected by elevated circulating free fatty acids. Moreover, insulin-stimulated oxidative and nonoxidative glucose disposal (i.e., insulin sensitivity) were enhanced during IGF-I treatment. Thus, IGF-I treatment leads to marked changes in lipid and protein oxidation, whereas, at the dose used, carbohydrate metabolism remains unaltered in the face of reduced insulin levels and enhanced insulin sensitivity. (J. Clin. Invest. 1993. 92:2249-2256.) Key words: anabolism • euglycemic clamp • indirect calorimetry $\bullet$ insulin-like growth factor • substrate oxidation.
\end{abstract}

\section{Introduction}

Growth hormone $(\mathrm{GH})^{1}$ stimulates hepatic synthesis and secretion of insulin-like growth factor-I (IGF-I) (1), which medi-

This work was presented in part at the 53rd Annual Meeting of the American Diabetes Association, Las Vegas, NV, 12-15 June 1993.

Address reprint requests to Dr. Mehboob Hussain, Division of Endocrinology and Metabolism, Department of Internal Medicine, University Hospital, Rämistrasse 100, 8091 Zurich, Switzerland.

Received for publication 26 March 1993 and in revised form 22 June 1993.

1. Abbreviations used in this paper: AUC, areas under the curve; C-peptide, connecting peptide; $\mathrm{CV}$, coefficient of variation; $\mathrm{EE}$, energy expenditure; FFM, free fat mass; GH, growth hormone; Ra, rate of glucose appearance; $\mathrm{Rd}$, rate of glucose disposal.

J. Clin. Invest.

(C) The American Society for Clinical Investigation, Inc. $0021-9738 / 93 / 11 / 2249 / 08 \quad \$ 2.00$

Volume 92, November 1993, 2249-2256 ates most of the growth-promoting activity of $\mathrm{GH}(2,3)$. In GH-deficient rodents (3-5) and in GH-insensitive Laron-type dwarfism, (6) IGF-I administration has growth-promoting properties.

Apart from its role as mediator of GH, IGF-I posesses insulin-like activity in vitro $(7,8)$ and in vivo (9-12). In normal rats, intravenously administered IGF-I results in hypoglycemia (9). Intravenous (i.v.) bolus injections of IGF-I in humans rapidly induce hypoglycemia, similarly to insulin (10). The effects of IGF-I infusion on glucose turnover, circulating FFA, and amino acids under euglycemic clamp conditions in humans are comparable to those of insulin $(11,12)$.

However, divergent effects of insulin and IGF-I have been described in fasted rats (13) and pancreatectomized diabetic dogs (14). Differences between the effects of IGF-I and of insulin may be due to $(a)$ the tissue distribution of their respective receptors and $(b)$ the IGF-I specific inhibition of growth hormone and insulin secretion (15-18). Whereas skeletal muscle tissue has type I IGF as well as insulin receptors (7), other target cells of insulin such as adipocytes (19) and hepatocytes (20) have few, if any, functional type I IGF receptors. In these latter tissues, the biological effects of IGF-I are due to crossreaction of IGF-I with the insulin receptor. Because the affinity of IGF-I to the insulin receptor is only $1 \%$ of that of insulin (19), only large doses of IGF-I affect lipolysis and hepatic glucose production. IGF-I administration in healthy humans is followed by a dose-dependent reduction of insulin and $\mathrm{GH}$ secretion. At the same time, fasting glucose levels and glucose tolerance remain unchanged suggestive of increased insulin sensitivity, either directly and/or indirectly via reduced insulin and GH levels, during administration of $\operatorname{IGF}-\mathrm{I}(16,18)$.

Although the insulin-like effects of IGF-I have been extensively examined, much less is known about other metabolic effects of IGF-I treatment in humans. Whereas IGF-I is considered as the mediator of the growth promoting actions of growth hormone, it remains unclear whether or not any metabolic effects of IGF-I treatment in humans are similar to previously shown effects of GH treatment. We have therefore treated healthy adults with IGF-I for $5 \mathrm{~d}$ and we describe the effects on energy expenditure and total body fuel metabolism in the basal state as well as during physiological hyperinsulinemia.

\section{Methods}

Subjects. Eight healthy volunteers (five males and three females; age $28 \pm 2 \mathrm{yr}$, range $25-30$; body mass index $21.5 \pm 2.7 \mathrm{~kg} / \mathrm{m}^{2}$, range 18.4 25.9 ) were studied. None had any evidence of somatic or mental illness as assessed by history, clinical and routine laboratory examination, and chest X-ray. Glycosylated hemoglobin $\left(\mathrm{HbA}_{1 \mathrm{c}}\right)$ was within the normal range in all subjects. Female participants were taking monophasic oral contraceptives. Written informed consent was obtained from each volunteer. The study protocol had been approved by the ethic commitee of the University Hospital of Zürich. 
Experimental design. The study consisted of two periods of $5 \mathrm{~d}$ each (Fig. 1a) during which the subjects received a continuous subcutaneous infusion of $10 \mu \mathrm{g} / \mathrm{kg} \cdot \mathrm{h}$ recombinant human IGF-I (rhIGF-I, Ciba-Geigy AG, Basel, Switzerland), or $0.9 \%$ saline via a portable minipump (MRS-1, Disetronic AG, Burgdorf, Switzerland) in a crossover, randomized fashion. An interval of $2.5 \mathrm{~d}$ was allowed between the two treatment periods. A sucrose-free diet of $30 \mathrm{kcal} / \mathrm{kg} \cdot \mathrm{d}$ ( $50 \%$ carbohydrates, $30 \%$ lipids, $20 \%$ proteins; $30 \%$ of calories at each main meal, $10 \%$ as bedtime snack) was started $5 \mathrm{~d}$ before the study and was maintained throughout the study period. Breakfast, lunch, and supper were served at 8:00 a.m., noon, and 6:00 p.m., respectively. The bedtime snack was taken at 10:00 p.m. On days 3-5 of the study, breakfast was served after the respective examinations (see below) had been performed. In addition, not more than 30 min of light physical exercise per day was allowed during this time. Blood samples were drawn daily at 8:00 a.m. after a 10-h overnight fast for determinations of sodium, potassium, creatinine, urea, uric acid, glucose, insulin, connecting peptide (C-peptide), GH, and IGF-I.

On day 3, a L-arginine stimulation test was carried out. L-Arginine $(0.5 \mathrm{~g} / \mathrm{kg}$, maximally $30 \mathrm{~g})$ was infused i.v. at a constant rate over 30 min. Blood was drawn at $-15,0,10,20,30,45,60,90$, and $120 \mathrm{~min}$ for determinations of plasma glucose, circulating insulin, C-peptide, $\mathrm{GH}$, IGF-I, and glucagon. On day 4, an intravenous glucose tolerance test was performed. Glucose was administered into a cannulated cubital vein ( $25 \mathrm{~g}$ within $2 \mathrm{~min}$ i.v.). Blood was collected from a contralateral vein at $-15,0,2,5,10,20,30,45,60,90$, and 120 min for determinations of plasma glucose, insulin, C-peptide, GH, and IGF-I.

Finally, a euglycemic, hyperinsulinemic clamp, combined with the isotope dilution technique and indirect calorimetry was performed on day 5 (Fig. $1 b$ ). A Venflon (Viggo-Spectromed, Helsingborg, Sweden) cannula was inserted into an antecubital vein for infusions of $\left[3-{ }^{3} \mathrm{H}\right]-$ glucose, insulin, and unlabeled glucose. Another cannula was inserted into a contralateral arterialized wrist vein for blood sampling (21). At time 0 min, a primed $(30 \mu \mathrm{Ci})$, continuous $(0.3 \mu \mathrm{Ci} / \mathrm{min})$ infusion of

a)

day

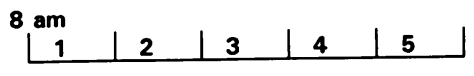

hIGF I (10 $\mu \mathrm{g} / \mathrm{kg} \times \mathrm{h})$ or saline $(0.9 \%)$ s.c.

Fasting blood sample

L-arginine stimulation

( $30 \mathrm{~g}$ i.v. in $30 \mathrm{~min}$ )

Intravenous glucose tolerance test (25 g)

Euglycemic hyperinsulinemic clamp

$24 \mathrm{~h}$ urine collection

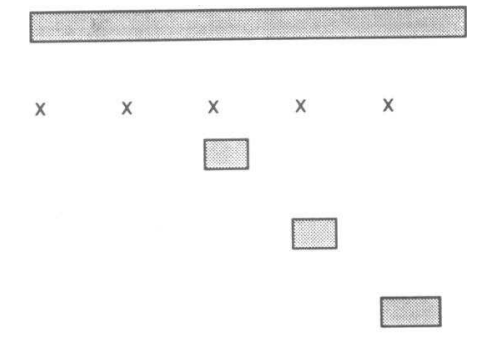

b)

time (minutes)

IhIGF I (10 $\mu \mathrm{gg} / \mathrm{kg} \times \mathrm{h})$

or saline $(0.9 \%)$ s.c.

3H-glucose infusion i.v.

Insulin infusion i.v.

Glucose $(200 \mathrm{~g} / \mathrm{l})$ infusion i.v.

Indirect calorimetry

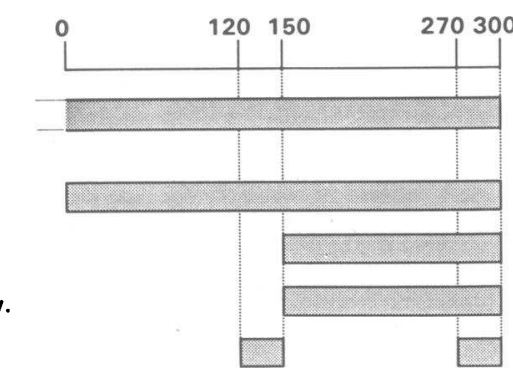

Figure 1. Schematic diagram of $(a)$ study protocol and $(b)$ euglycemic, hyperinsulinemic clamp.
HPLC-purified [ $\left.3-{ }^{3} \mathrm{H}\right]$-glucose (22) (DuPont-New England Nuclear, Boston, MA) was started and continued for $300 \mathrm{~min}$. After a 150-min equilibration period, insulin (Actrapid, Novo-Nordisk, Denmark) was infused for another $150 \mathrm{~min}$ at a constant rate of 0.6 (saline treatment) or $0.7 \mathrm{mU} / \mathrm{kg} \cdot \mathrm{min}$ (IGF-I treatment). A slightly higher insulin infusion rate was chosen during IGF-I administration to compensate for the reduced endogenous insulin levels during IGF-I treatment (16) whereby comparable peripheral insulin levels were achieved in both situations (see results section). The plasma glucose concentration was maintained constant at $5 \mathrm{mmol} /$ liter, using a variable glucose infusion $(200 \mathrm{~g} /$ liter $)$. The last 30 -min periods during basal conditions ( 120 $150 \mathrm{~min}$ ) and again during insulin stimulation (270-300 min) were considered to represent a steady state. Blood samples for determination of insulin, C-peptide, total IGF-I, FFA, and the specific activity of glucose were collected at $-30,0,90,120,130,140,150,180,240,260$, $270,280,290$, and $300 \mathrm{~min}$, respectively. Glucose concentration was monitored every 5-10 min. Respiratory gas exchange and energy expenditure were measured by indirect calorimetry using a computerized, flowthrough canopy gas analyzer system (Deltatrac; Datex, Helsinki, Finland). To determine urinary urea and uric acid excretion, and creatinine clearance, 24-h urine samples were collected from day 4 to day 5 . Urine was also collected on day 5 during the clamp study for calculations of protein oxidation during indirect calorimetry. Fat free mass (FFM) was measured on day 5 using the bioimpedance method (22).

Analytical determinations. Plasma glucose was measured immediately after blood sampling using an automated glucose-oxidase method (Glucose Analyzer 2, Beckman Instruments, Inc., Fullerton, CA). Blood samples for glucagon were collected in special tubes (lithium heparin $143 \mathrm{IU} / 10 \mathrm{ml}$ and aprotinin $4000 \mathrm{IU} / 10 \mathrm{ml}$; Bayer, Zürich, Switzerland), centrifuged immediately during $15 \mathrm{~min}$ at $1,550 \mathrm{~g}$ at $4^{\circ} \mathrm{C}$, and the supernatant was frozen at $-20^{\circ} \mathrm{C}$ until analysis. Insulin, $\mathrm{C}$-peptide, and $\mathrm{GH}$ levels were measured in serum (18) with commercially available RIA kits (Medipro AG, Teufen, Switzerland). Lower detection limits were $36 \mathrm{pmol} /$ liter for insulin, $70 \mathrm{pmol} /$ liter for Cpeptide, and $0.18 \mathrm{ng} / \mathrm{ml}$ for $\mathrm{GH}$. For statistical analysis, 0 levels were assigned to the lower detection limit of the corresponding assay. Interassay coefficients of variation (CV) were $6.5 \%$ and $8.0 \%$ ( 100 and 480 $\mathrm{pmol} /$ liter) for insulin, $4.5 \%$ and $3.4 \%$ (470 and $1500 \mathrm{pmol} /$ liter) for C-peptide, and $5.0 \%$ ( $730 \mathrm{ng} /$ liter ) for $\mathrm{GH}$, respectively. The glucagon RIA was performed according to Christofides (23). Interassay CV were $12.6 \%$ and $10.8 \%$ ( 4.5 and $33 \mathrm{pmol} /$ liter).

Total IGF-I levels in serum were measured by RIA according to a modification of a previously described method (24). $250 \mu \mathrm{l}$ of serum was extracted through Sep-Pack cartridges (Waters Associates, Milford, MA) according to instructions supplied by the manufacturer for separating IGF from IGF-binding proteins (IGFBPs). The eluate was steam dried, lyophilized, and dissolved in PBS containing $0.2 \%$ HSA for assays of IGF-I and II. $100 \mu$ l of sample or of rhIGF-I standards, 200 $\mu \mathrm{l}$ of IGF-I antiserum diluted 1:1,000, and $100 \mu \mathrm{l}$ of ${ }^{125}$ I-IGF-I were incubated for $24 \mathrm{~h}$ at $4^{\circ} \mathrm{C}$. Antibody-bound radioactivity was precipitated with $40 \mu \mathrm{g}$ of rabbit gamma globulin and $50 \mu \mathrm{l}$ of goat anti-rabbit gamma globulin, diluted 1:7. Interassay and intraassay CV were $15.8 \%$ and $10.5 \%$, respectively.

FFA were determined colorimetrically with a commercial kit (Wako Chemicals, Neuss, FRG) with an interassay CV of 6.7\%. Tritiated glucose activity was determined after deproteinizing plasma with $0.3 \mathrm{mmol} /$ liter $\mathrm{Ba}(\mathrm{OH})_{2}$ and $0.3 \mathrm{mmol} /$ liter $\mathrm{ZnSO}_{4}$. Subsequently the supernatant was evaporated under vacuum. The pellet was resuspended in distilled water, supplemented with $5 \mathrm{ml}$ of Aqualuma Plus (Lumac, Shaesburg, The Netherlands), and counted for $3 \mathrm{~h}$ in a liquid scintillation counter.

Determinations of serum urea, creatinine, uric acid, sodium, and potassium were performed in an auto-analyzer (model $747 \mathrm{Hitachi}$, Zürich). Creatinine clearance was calculated from serum and urine creatinine levels as in the Geigy Scientific Charts (25).

All samples (except routine chemistry) were analyzed in triplicate (tritiated glucose activity) or duplicate (all other) in one assay in one or 
two dilutions. Care was taken to examine samples from the same individual in the same assay.

Calculations. Rates of glucose disposal (Rd) and glucose appearance $(\mathrm{Ra})$ were estimated according to the non-steady-state equations of Steele as modified by deBodo et al. (26). A pool fraction of 0.65 and a distribution volume of $220 \mathrm{ml} /$ liter for glucose were assumed. Hepatic glucose output was calculated by subtracting the rate of exogenously infused glucose necessary to maintain euglycemia (M-value) from the isotopically determined overall $\mathrm{Ra}$. In calculating nonprotein energy expenditure (EE), the gaseous exchange attributable to protein oxidation was subtracted from total gaseous exchange under the assumption that for each gram of nitrogen excreted in urine, 5.95 liters of $\mathrm{O}_{2}$ was consumed, and 4.97 liters of $\mathrm{CO}_{2}$ was produced. The protein oxidation rate was estimated from urinary nitrogen excretion ( $1 \mathrm{~g} \mathrm{ni-}$ trogen $=6.25 \mathrm{~g}$ protein $)$. Urinary nitrogen excretion was estimated on the assumption that $90 \%$ of the nitrogen appeared as urea. The proportion of nonprotein energy derived from fat and carbohydrate oxidation was calculated from the nonprotein respiratory quotient as previously described (27). During insulin infusion negative rates of hepatic glucose output were calculated in all subjects. Such underestimations of $\mathrm{Ra}$ are mainly accounted for by a model error (28). Since the M-value exceeded the isotopically determined glucose disposal during hyperinsulinemia, net nonoxidative glucose disposal ( $\operatorname{Rd}[$ nonox ]) was calculated by subtracting oxidative glucose disposal $(\operatorname{Rd}[\mathrm{ox}])$ from the $\mathrm{M}$ value. Energy expenditure is given in kilocalories per kilogram of FFM per day (see Fig. 6). Glucose turnover data are given in milligrams per kilogram of body weight per minute ( see Table II). Substrate oxidation rates are given in both units (see Fig. 6 and Table II) for easier comparison.

Statistics. All data are expressed as mean \pm SD. Areas under the curve (AUC) were calculated using the trapezoidal rule. Comparisons were performed using Wilcoxon's rank-sum test ( two tailed) for paired differences (29). A $P<0.05$ was considered statistically significant.

\section{Results}

Under IGF-I treatment seven of eight subjects developed slight generalized edema and gained $1.0 \pm 0.5 \mathrm{~kg}$ within $5 \mathrm{~d}$. Five subjects reported bilateral tenderness of the parotid gland and two noted slight frontal headache. The pulse rate increased between $9 \%$ and $15 \%$ in all subjects during IGF-I treatment. Blood pressure remained unchanged. No orthostatic weakness or dizziness was reported. FFM was unchanged during the two treatment periods (not shown).

Basal values. Plasma glucose, circulating insulin, and Cpeptide levels were within normal limits before the start of the infusions and remained unaltered during the control infusions with $0.9 \%$ saline (Fig. 2). Total IGF-I levels were within normal values during the control period $(24.1 \pm 6.7)$ and rose to $101.1 \pm 18.5 \mathrm{nmol} /$ liter after $24 \mathrm{~h}$ of IGF-I treatment and remained at that level thereafter $(P<0.01)$. Fasting plasma glucose levels decreased from $4.7 \pm 0.3$ to $4.3 \pm 0.3 \mathrm{mmol} /$ liter $(P$ $<0.04)$ on the third IGF-I treatment day remaining stable thereafter $(4.2 \pm 0.4 \mathrm{mmol} /$ liter on day $5, P<0.01 \mathrm{vs}$. control; Fig. 2). Insulin and C-peptide levels, initially $68.6 \pm 14.0$ and $557.5 \pm 122.1 \mathrm{pmol} /$ liter, decreased significantly on the second day to $37.9 \pm 4.1(P<0.01)$ and $216.6 \pm 57.2 \mathrm{pmol} /$ liter $(P$ $<0.01$ ), respectively, and remained suppressed (Fig. 2). Similarly, GH levels were suppressed to below the detection limit of the RIA during IGF-I treatment from the third day onward ( $P$ $<0.02$; Fig. 2).

Serum sodium and potassium remained unchanged during both treatment periods (not shown). Serum urea, uric acid, and creatinine levels remained unaltered during saline and decreased significantly during IGF-I treatment (Fig. 2). This was

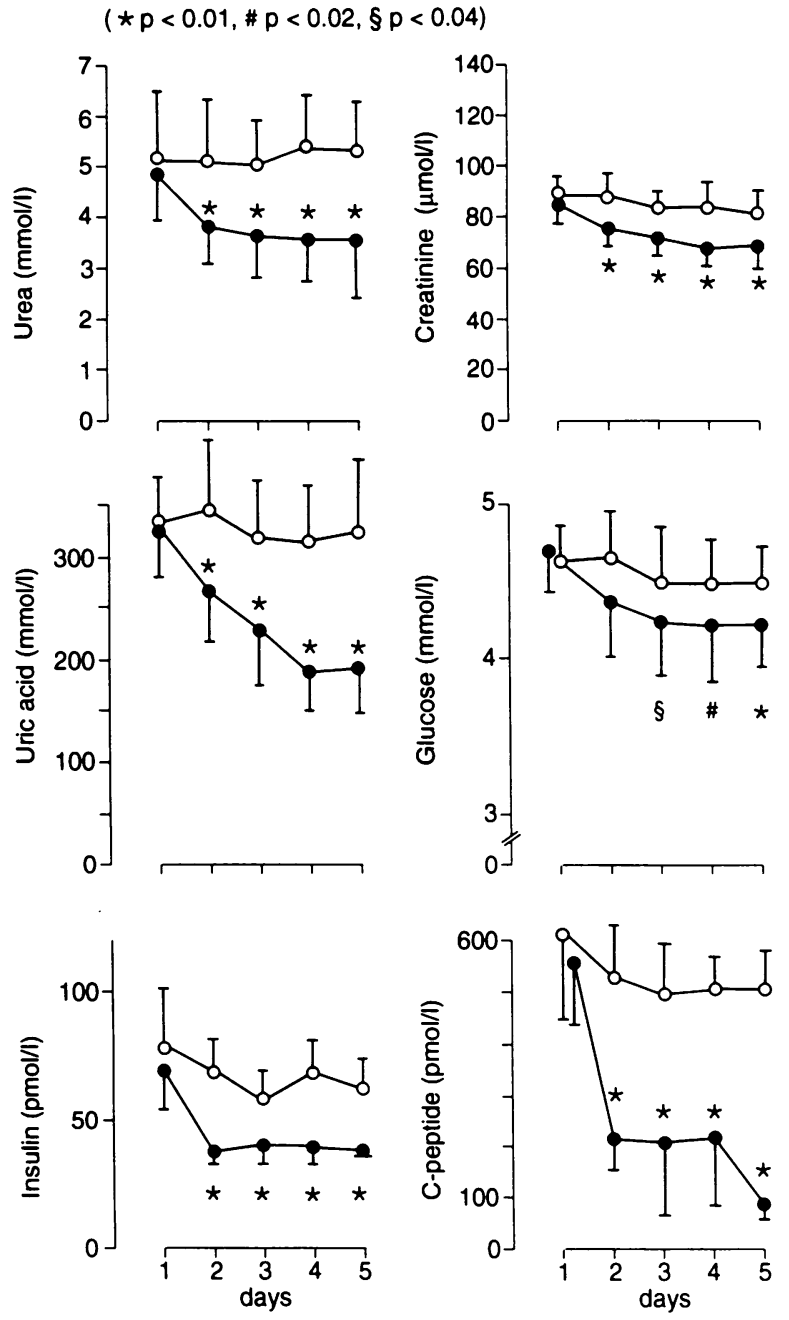

Figure 2. Fasting serum parameters during saline (O) and IGF-I 10 $\mu \mathrm{g} / \mathrm{kg} \cdot \mathrm{h}$ s.c.; $\bullet)$ treatment during $5 \mathrm{~d}$ in eight healthy subjects (mean $\pm \mathrm{SD} ;{ }^{*} P<0.01,{ }^{*} P<0.02,{ }^{\S} P<0.04$ ).

accompanied by an increase of creatinine clearance and a fall of urinary urea excretion on days 4-5 of IGF-I treatment, while uric acid excretion remained unchanged (Table I).

L-Arginine stimulation test. During IGF-I treatment AUC of insulin, C-peptide, and GH were significantly decreased to $60 \pm 12 \%(P<0.01), 59 \pm 24 \%(P<0.01)$, and $12 \pm 91 \%(P$ $<0.03$ ) of control, respectively (Fig. 3). Basal values and AUC of stimulated glucagon were unchanged $(91 \pm 24 \%$; NS), respectively as compared to those measured under saline treatment. Insulin, $\mathrm{GH}$, and glucagon secretion upon arginine stimulation were, however, not delayed by IGF-I treatment.

Intravenous glucose tolerance test. Glucose tolerance was unaltered during IGF-I treatment despite concomitantly reduced insulin levels (Fig. 4). AUC of insulin and C-peptide during the i.v. glucose tolerance test under IGF-I treatment were $65 \pm 14 \%$ and $53 \pm 10 \%$ of control $(P<0.01$ for both $)$, respectively. However, the insulin response to the intravenous glucose load was prompt and not delayed during IGF-I treatment.

Basal circulating FFA levels on day 5 (Fig. 5) were significantly elevated during IGF-I treatment $(867 \pm 307 \mu \mathrm{mol} /$ liter $)$ as compared with the control period $(613 \pm 185 \mu \mathrm{mol} / \mathrm{liter}, P$ $<0.02$ ). 

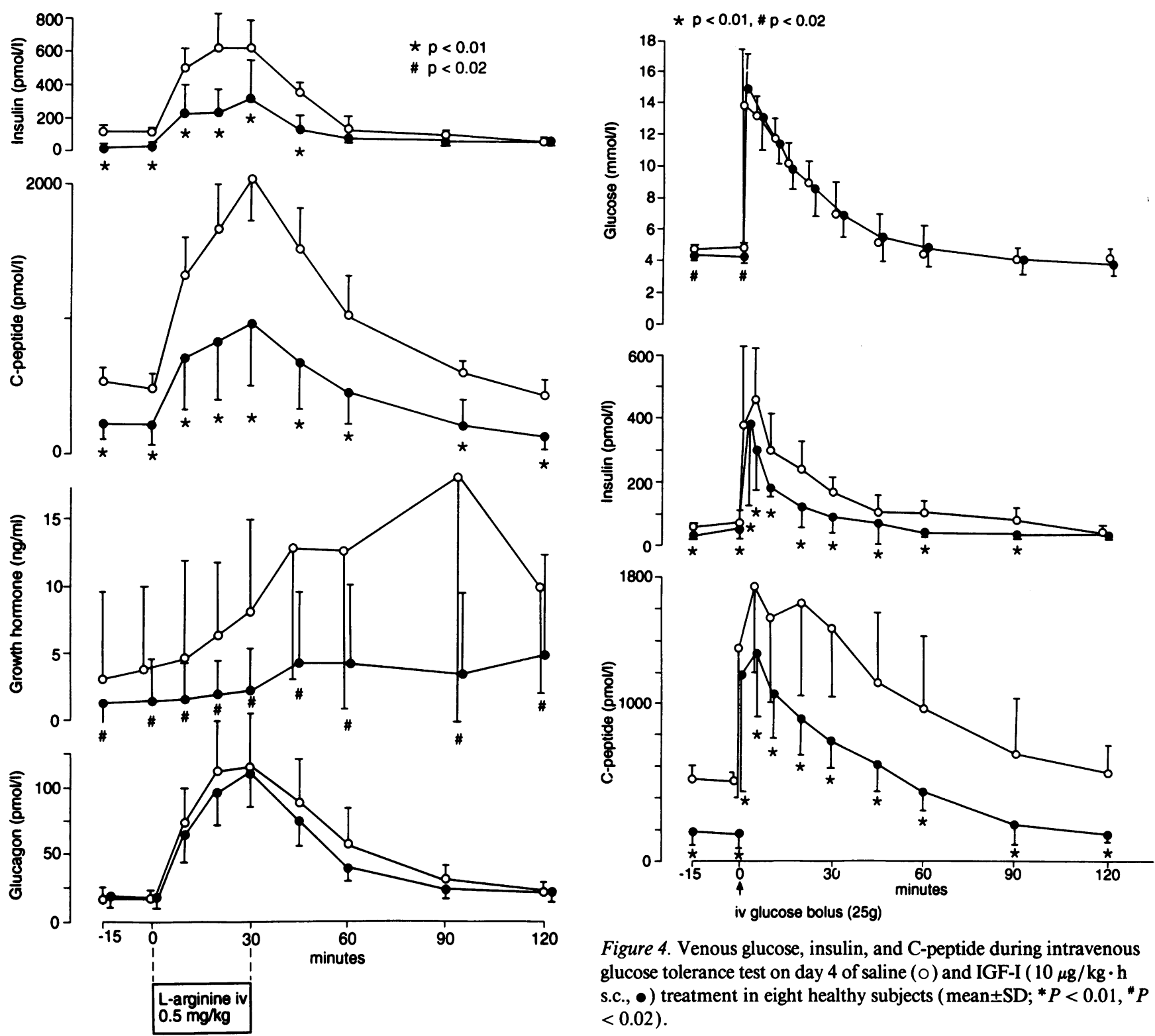

Figure 4. Venous glucose, insulin, and C-peptide during intravenous glucose tolerance test on day 4 of saline (O) and IGF-I $(10 \mu \mathrm{g} / \mathrm{kg} \cdot \mathrm{h}$ s.c., $\bullet$ ) treatment in eight healthy subjects (mean $\pm \mathrm{SD} ;{ }^{*} P<0.01,{ }^{*} P$ $<0.02$ ).

Figure 3. Venous insulin, C-peptide, growth hormone, and glucagon during L-arginine stimulation on day 3 of saline $(0)$ and IGF-I (10 $\mu \mathrm{g} / \mathrm{kg} \cdot \mathrm{h}$ s.c., $\bullet$ ) treatment in eight healthy subjects (mean $\pm \mathrm{SD} ;{ }^{*} P$ $<0.01,{ }^{*} P<0.02$ ).

Indirect calorimetry and euglycemic clamp. EE (Fig. 6) was markedly elevated in all subjects during IGF-I administration (i.e., $33.20 \pm 4.59$ as compared with $29.97 \pm 3.21 \mathrm{kcal} /$ $\mathrm{kg}(\mathrm{FFM}) \cdot \mathrm{d}$ during saline; $P<0.02)$. In the basal state, lipid

Table I. Urinary Urea and Uric Acid Excretion,

and Creatinine Clearance (Mean $\pm S D)$ on Days 4-5 during Saline and IGF-I $(10 \mu \mathrm{g} / \mathrm{kg} \cdot \mathrm{h}$ s.c.) Treatment in Eight Healthy Subjects

\begin{tabular}{lcc}
\hline & Saline & IGF-I \\
\hline Urea excretion $(\mathrm{mmol} / \mathrm{d})$ & $564.5 \pm 100.6$ & $492.0 \pm 83.9^{*}$ \\
Uric acid excretion $(\mathrm{mmol} / \mathrm{d})$ & $3.61 \pm 1.20$ & $3.93 \pm 1.00$ \\
Creatinine clearance $(\mathrm{ml} / \mathrm{min})$ & $122.63 \pm 16.95$ & $145.88 \pm 29.73^{\ddagger}$
\end{tabular}

${ }^{*} P<0.01 ;{ }^{\ddagger} P<0.02$.

oxidation was enhanced during IGF-I treatment $(1.23 \pm 0.10$ vs. $0.90 \pm 0.10 \mathrm{mg} / \mathrm{kg} \cdot \min ; P<0.01)$ while protein oxidation was reduced $(0.60 \pm 0.15$ vs. $0.88 \pm 0.20 \mathrm{mg} / \mathrm{kg} \cdot \min ; P<0.02)$ and carbohydrate oxidation unchanged $(1.24 \pm 0.28$ vs. $1.22 \pm 0.25 \mathrm{mg} / \mathrm{kg} \cdot \min )$. Postabsorbtive appearance rate of glucose was comparable during the two study periods, although the rates tended to be slightly lower during IGF-I $(1.52 \pm 0.13$ $\mathrm{mg} / \mathrm{kg} \cdot \mathrm{min})$ as compared with saline treatment $(1.75 \pm 0.44$ $\mathrm{mg} / \mathrm{kg} \cdot \mathrm{min}$ ). During the hyperinsulinemic clamp (Table II), plasma glucose and circulating insulin levels were comparable (saline vs. IGF-I $5.0 \pm 0.3$ vs. $4.9 \pm 0.3 \mathrm{mmol} / \mathrm{liter}$ and $249.9 \pm 55.2$ vs. $242.5 \pm 43.9 \mathrm{pmol} / \mathrm{liter}$ ). However, insulin-stimulated glucose uptake (M-value) was considerably greater during IGF-I treatment $(5.1 \pm 1.2 \mathrm{mg} / \mathrm{kg} \cdot \mathrm{min})$ than during saline administration $(4.3 \pm 1.2 \mathrm{mg} / \mathrm{kg} \cdot \min , P<0.02)$. This was due to enhanced $\operatorname{Rd}[0 x](2.38 \pm 0.39$ vs. $1.96 \pm 0.48 \mathrm{mg} /$ $\mathrm{kg} \cdot \min ; P<0.05)$ as well as enhanced $\mathrm{Rd}$ [ nonox] ( $3.12 \pm 0.98$ vs. $2.33 \pm 1.21 \mathrm{mg} / \mathrm{kg} \cdot \mathrm{min} ; P<0.05$ ).

Under IGF-I treatment, insulin infusion led to a more pronounced reduction of circulating FFA (to $47 \pm 26 \mu \mathrm{mol} /$ liter) than during saline treatment (to $108 \pm 99 \mu \mathrm{mol} / \mathrm{liter}, P$ 


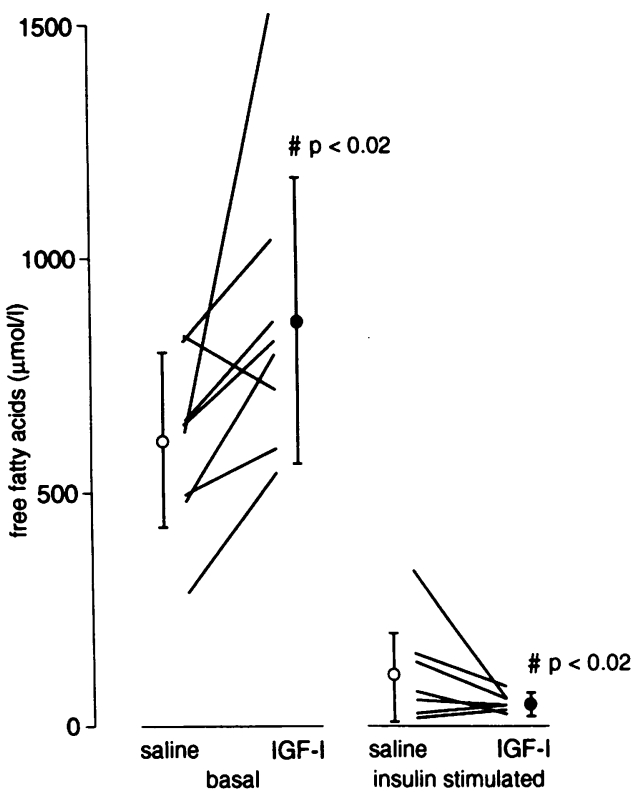

Figure 5. Individual values and mean \pm SD of circulating FFA in the basal state and during insulin stimulation on day 5 of saline and IGF-I $\left(10 \mu \mathrm{g} / \mathrm{kg} \cdot \mathrm{h} \mathrm{s}\right.$.c.) treatment in eight healthy subjects $\left({ }^{*} P<0.02\right)$.

$<0.02)$. Lipid oxidation rates were, however, similar during the hyperinsulinemic clamp $(0.80 \pm 0.19$ during saline and $0.83 \pm .08 \mathrm{mg} / \mathrm{FFM} \cdot \mathrm{min}$ during IGF-I treatment; NS). In addition, insulin suppression of HGO was more marked during IGF-I $(-1.5 \pm 0.6 \mathrm{mg} / \mathrm{kg} \cdot \mathrm{min})$ than during saline administration $(-0.46 \pm 0.63 \mathrm{mg} / \mathrm{kg} \cdot \mathrm{min} ; P<0.03)$.

\section{Discussion}

In the present study we describe marked effects of a 5-d treatment with IGF-I on basal and insulin-stimulated fuel metabolism in healthy humans. Net lipid oxidation was enhanced, protein oxidation was reduced, and carbohydrate oxidation remained unchanged. These changes were accompanied by a rise in EE. Moreover, insulin sensitivity of the liver and of peripheral tissues was enhanced during IGF-I administration. In this context it is important to note that treatment with IGF-I over several days leads to a reduction of basal and stimulated insulin
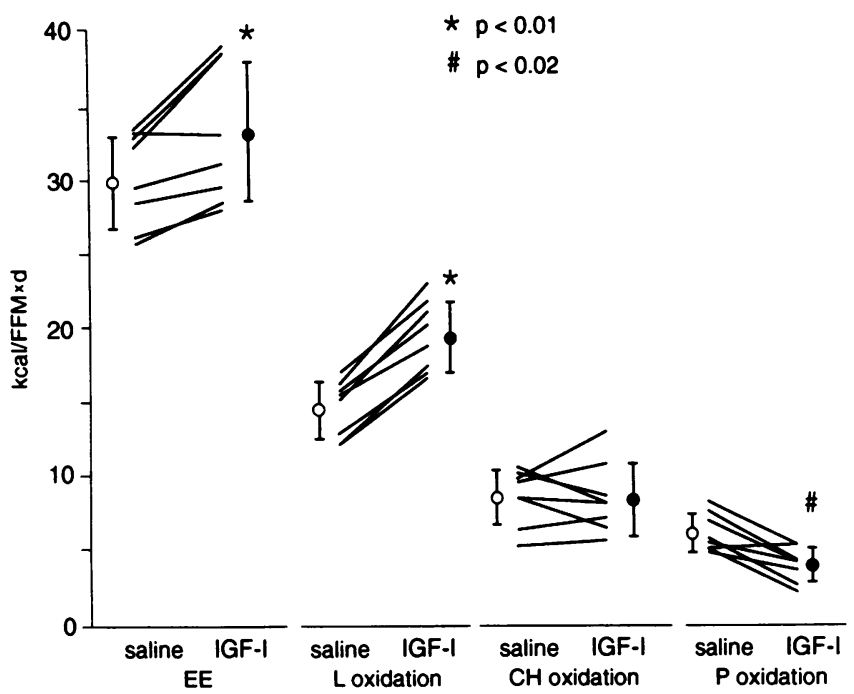

Figure 6. Individual values and mean $\pm \mathrm{SD}$ of resting $\mathrm{EE}$ and lipid (L), carbohydrate $(\mathrm{CH})$, and protein $(\mathrm{P})$ oxidation (in $\mathrm{kcal} / \mathrm{FFM} \cdot \mathrm{d}$ ) on day 5 of saline and rhIGF-I $(10 \mu \mathrm{g} / \mathrm{kg} \cdot \mathrm{h} \mathrm{s}$ s.c.) treatment in eight healthy subjects $\left({ }^{*} P<0.01,{ }^{*} P<0.02\right)$.

and GH secretion (16, 18, and Fig. 2) that may be responsible for some of the findings in this study and may also account for some of the discrepancies between this and previously reported studies using acute infusions of IGF-I.

During IGF-I treatment glucose tolerance did not change despite partial suppression of insulin and GH secretion (16, 18). The present report extends these findings by showing that, although IGF-I reduces basal and stimulated insulin secretion, the reaction of the $\beta$ cell to stimuli (arginine and glucose) remains prompt and not delayed. Similar results have been observed in hyperglycemic clamping under acute IGF-I infusions (30). In contrast to a previous study (18), we found slightly but significantly decreased fasting glucose levels under IGF-I treatment. A higher dose of IGF-I in a GH-insensitive (Laron) dwarf caused hypoglycemia and impaired glucose tolerance (31). The IGF-I dose used in the present study was sufficient to lower fasting glucose, probably via increased insulin sensitivity and/or diminished $\mathrm{GH}$ secretion while insulin secretion remained prompt and sufficient enough to keep glucose toler-

Table II. Glucose Turnover and Substrate Oxidation Rates (Mean $\pm S D$ ) in the Basal State and during Hyperinsulinemic, Euglycemic Clamp on Day 5 of Saline and IGF-I (10 $\mu \mathrm{g} / \mathrm{kg} \cdot \mathrm{h} \mathrm{s.c.)}$ Treatment in Eight Healthy Subjects

\begin{tabular}{|c|c|c|c|c|}
\hline & \multicolumn{2}{|c|}{ Basal } & \multicolumn{2}{|c|}{ Hyperinsulinemic clamp } \\
\hline & Saline & IGF-I & Saline & IGF-I \\
\hline Glucose infusion rate $(\mathrm{M}$-value $)(\mathrm{mg} / \mathrm{kg} \cdot \mathrm{min})$ & & & $4.29 \pm 1.24$ & $5.49 \pm 1.05^{\ddagger}$ \\
\hline Hepatic glucose output $(\mathrm{mg} / \mathrm{kg} \cdot \mathrm{min})$ & $1.75 \pm 0.44$ & $1.52 \pm 0.13$ & $-0.46 \pm 0.63$ & $-1.62 \pm 1.05^{\S}$ \\
\hline Glucose appearance rate $(\mathrm{Ra})(\mathrm{mg} / \mathrm{kg} \cdot \mathrm{min})$ & $1.75 \pm 0.44$ & $1.52 \pm 0.13$ & $3.39 \pm 0.76$ & $3.91 \pm 0.85$ \\
\hline \multicolumn{5}{|l|}{ Glucose disposal rate $(\mathrm{Rd})(\mathrm{mg} / \mathrm{kg} \cdot \mathrm{min})$} \\
\hline Oxidative & $1.22 \pm 0.25$ & $1.24 \pm 0.29$ & $1.96 \pm 0.48$ & $2.38 \pm 0.39^{\prime \prime}$ \\
\hline Nonoxidative & $0.52 \pm 0.34$ & $0.29 \pm 0.30$ & $2.33 \pm 1.21$ & $3.12 \pm 0.98^{\prime \prime}$ \\
\hline Lipid oxidation rate $(m g / k g \cdot m i n)$ & $0.90 \pm 0.10$ & $1.23 \pm 0.10^{*}$ & $0.61 \pm 0.14$ & $0.69 \pm 0.08$ \\
\hline Protein oxidation rate $(\mathrm{mg} / \mathrm{kg} \cdot \mathrm{min})$ & $0.88 \pm 0.20$ & $0.60 \pm 0.15^{\ddagger}$ & $0.85 \pm 0.20$ & $0.62 \pm 0.13^{\ddagger}$ \\
\hline
\end{tabular}

${ }^{*} P<0.01 ;{ }^{\ddagger} P<0.02 ;{ }^{\S} P<0.03 ; \quad " P<0.05$. 
ance unaltered. No change of carbohydrate oxidation and glucose turnover was demonstrable under IGF-I treatment. The residual insulin levels in the portal vein and the increased insulin sensitivity apparently kept HGO from rising.

Insulin sensitivity of the liver and of peripheral tissue may be increased by several mechanisms. Reduced basal glucose as well as reduced insulin levels may enhance insulin sensitivity $(32,33)$. In addition, the reduction of GH levels in acromegalics is accompanied by improved glucose tolerance and sensitivity to insulin $(34,35)$. The reduction of GH levels during IGF-I treatment may also have contributed to the enhanced insulin sensitivity. In preliminary experiments we have observed that the simultaneous treatment of GH-deficient subjects with IGFI together with $\mathrm{GH}$ is accompanied by few changes in tissue sensitivity to insulin, supporting the idea that the suppression of GH secretion plays a major role in the effects of IGF-I on glucose metabolism (M. A. Hussain, manuscript in preparation).

Glucose levels may have remained normal despite decreased insulin levels probably by an increase in insulin sensitivity and/or concerted glucose-lowering effects of IGF-I and insulin on skeletal muscle via their respective receptors (30). In contrast, lipolysis may have remained unopposed due to a lack of functional IGF-I receptors on adipocytes (19) and low circulating insulin levels. Inability of IGF-I to suppress FFA levels has previously been reported in rats $(9,13)$. The ensuing rise in circulating FFA delivered the substrate for the elevated lipid oxidation shown in this study. We have no data at present on circulating ketone bodies during IGF-I therapy. However, marked ketogenesis has been reported in a case of a Laron dwarf who received large amounts of rhIGF-I leading to fasting hypoglycemia (31). The unchanged basal and stimulated glucagon levels in the face of reduced insulin levels may also have contributed to enhanced ketogenesis (36). It appears that elevated levels of IGF-I during a period of several days do not alter the glucagon response to arginine (Fig. 3). These data confirm results obtained with the perfused rat pancreas (17). However, using an entirely different study design, Kerr et al. (37) have reported a somewhat diminished glucagon response to IGF-Iinduced hypoglycemia as compared to acute insulin-induced hypoglycemia. These apparent discrepancies are likely to be due to the different stimuli of glucagon secretion and maybe also to the higher and acutely administered IGF-I doses used by Kerr et al. (37).

The elevation of circulating FFA was not accompanied by a substantial reduction in glucose metabolism. Nonetheless, the slight but statistically not significant reduction in oxidative and nonoxidative glucose disposal during IGF-I therapy may be explained by substrate competition (Randle cycle). Whereas insulin is relatively inefficient in counteracting lipolysis in acromegalics and in normal subjects receiving $\mathrm{GH}$ infusions $(34,38)$, circulating FFA levels were readily suppressed by exogenous insulin infusion in our subjects during IGF-I treatment. Moreover, this insulin effect was more pronounced during IGF-I administration than in the control phase with saline, possibly due to reduced basal insulin and $\mathrm{GH}$ secretion and consequently enhanced sensitivity of adipose tissue to insulin.

IGF-I administration also reduced protein oxidation as a reflection of a decrease in protein breakdown (11-13, 39). Studies in adult rats (13) and growing lambs (39) demonstrate that IGF-I inhibits protein breakdown. Inhibition of proteoly- sis by IGF-I has also been reported during acute IGF-I infusion and euglycemic clamping in humans $(11,12)$. However, in these latter studies much larger doses of IGF-I were acutely infused such that cross-reaction of IGF-I with insulin receptors could not be excluded by the investigators. All effects of the infused IGF-I mimicked those of insulin and glucose metabolism was stimulated. In contrast, basal glucose metabolism remained unchanged after $5 \mathrm{~d}$ of IGF-I administration in the present study, whereas protein oxdidation was clearly reduced, suggesting that all the effects observed with the smaller, nonhypoglycemic doses of IGF-I are mediated by the type I IGF receptor. Anticatabolic effects of IGF-I have also been demonstrated during dietary restriction in rats (40) and humans (41). In the present study we find consistent protein-sparing effects in healthy subjects also while on a controlled isocaloric diet.

Most of the increase in EE during IGF-I treatment may be accounted for by increased net fat oxidation since more FFA (and presumably ketone bodies) are available. Increased glucose turnover, as found in acromegalics (42), can be dismissed as a possible explanation for elevated EE because of the unchanged basal hepatic glucose production under IGF-I treatment. The conversion of thyroxine to triiodothyronine is enhanced under the influence of IGF-I at lower TSH levels (M. Hussain, preliminary observation ) which might be responsible for enhanced EE, thermogenesis, and increased heat dissipation (43). Some of the extra EE is required for the increased work load of the heart. A $10 \%$ rise of pulse rate and unchanged blood pressure values, as found in our subjects under IGF-I treatment, only leads to a $1-2 \%$ rise in the basal metabolic rate (44). Thus, the elevated cardiac work by no means explains the elevated $\mathrm{EE}$ in the present study.

Most of the circulating IGF-I is noncovalently bound to specific binding proteins (IGFBPs). $80 \%$ of the IGF circulates in the form of a heterotrimer together with an IGFBP-3 subunit and an acid-labile subunit. The serum levels of this complex is dependent on GH secretion. IGF-I therapy in the doses used in this study lead to an altered IGFBP profile with an elevation of IGFBP-1 and -2 levels (45). Unbound IGF-I and IGF-I associated to IGFBP-1 and 2 can cross the capillary barrier and reach target tissues (46). Therefore, a change of the IGFBP profile may also have contributed to the metabolic effects observed in this study.

IGF-I is considered to be the mediator of growth-promoting actions of growth hormone. GH treatment in normal and GH-deficient subjects is accompanied by elevated IGF-I levels, reduced protein oxidation, and elevated EE in the face of enhanced lipolysis and lipid oxidation $(34,36,38,47,48)$. GH treatment also leads to elevated insulin levels and insulin resistance (48-51). As in the case of GH (38), IGF-I treatment is also accompanied by such effects on fuel combustion, but unlike GH, IGF-I treatment leads to a reduction of insulin secretion and to enhanced insulin sensitivity (16). Whereas protein breakdown is inhibited by nonhypoglycemic doses of IGF-I, stimulation of muscle protein synthesis may be an effect of $\mathrm{GH}$ not shared by IGF-I (5) or else GH may be necessary for the prevention of hypoglycemia (52) and the induction of even higher IGF-I levels which may stimulate protein synthesis (39, 52). Anabolism seems to be at its highest efficiency when GH, IGF-I, and insulin act in concert (52). Among these hormones, insulin seems to be the only one that physiologically stimulates lipogenesis, whereas GH and IGF-I (at nonhypoglycemic lev- 
els) allow the mobilization of caloric reserves from adipose tissue, albeit by different mechanisms.

Our data reveal differences between the effects of IGF-I and of those which have previously been shown of $\mathrm{GH}$ and insulin and may help understand the roles of these hormones in growth and metabolic homeostasis. Moreover, IGF-I may be a promising therapeutic agent in catabolic states without the adverse insulin antagonistic actions of $\mathrm{GH}$ and in situations where GH is ineffective (53).

\section{Acknowledgments}

We thank Yvonne Glatz and Dr. Sylvia E. Jäggi-Groisman for their superb technical assistance, the dieticians of the University Hospital of Zurich for their invaluable help, and Drs. Christian Bauer and Christoph Schmid for critical review of the manuscript.

This work was supported by the Swiss National Science Foundation (grant 32-31281-91).

\section{References}

1. Schwander, J. C., C. Hauri, J. Zapf, and E. R. Froesch. 1983. Synthesis and secretion of insulin-like growth factor and its binding protein by the perfused rat liver: dependence on growth hormone status. Endocrinology. 113:297-305.

2. Salmon, W. D., Jr., and W. H. Daughaday. 1957. A hormonally controlled serum factor which stimulates sulfate incorporation by cartilage in vivo. J. Lab. Clin. Med. 49:825-836.

3. Van-Buul-Offers, S., I. Ueda, and J. L. Van den Brande. 1986. Biosynthetic somatomedin C (SM-C/IGF-I) increases the length and weight of Snell dwarf mice. Pediatr. Res. 20:825-827.

4. Schoenle, E., J. Zapf, R. E. Humbel, and E. R. Froesch. 1982. Insulin-like growth factor I stimulates growth in hypophysectomized rats. Nature (Lond.). 323:169-171.

5. Guler H. P., J. Zapf, E. Scheiwiller, and E. R. Freosch. 1988. Recombinant human insulin like growth factor I stimulates growth and has distinct effects on organ size. Proc. Natl. Acad. Sci. USA. 85:4889-4893.

6. Laron, Z., S. Anin, Y. Klipper-Aurbach, and B. Klinger. 1992. Effects of insulin-like growth factor on linear growth, head circumference, and body fat in patients with Laron-type dwarfism. Lancet. 339:1258-12.

7. Poggi, C., Y. Le Marchand-Brustel, J. Zapf, E. R. Froesch, and P. Freychet. 1979. Effects and binding of insulin-like growth factor in the isolated soleus muscle of lean and obese mice. Endocrinology. 195:732-730.

8. King, G. L., C. R. Kahn, M. M. Rechler, and S. P. Nissley. 1980. Direct demonstration of separate receptors for growth and metabolic activities of insulin and multiplication-stimulating activity (an insulin-like growth factor) using antibodies to the insulin receptor. J. Clin. Invest. 66:130-140.

9. Zapf, J., C. Hauri, M. Waldvogel, and E. R. Froesch. 1986. Acute metabolic effects and half-lives of intravenously administered insulin-like growth factors and II in normal and hypophysectomized rats. J. Clin. Invest. 77:1768-1775.

10. Guler, H. P., J. Zapf, and E. R. Froesch. 1987. Short-term metabolic effects of recombinant human insulin-like growth factor I in healthy adults. $N$ Engl. J. Med. 217:137-140.

11. Boulware, S. D., W. V. Tambourlane, L. S. Mathews, and R. S. Sherwin. 1992. Diverse effects of insulin-like growth factor I on glucose, lipid, and amino acids. Am. J. Physiol. 262:E130-E133.

12. Turkalj, I., U. Keller, R. Ninnis, S. Vosmeer, and W. Stauffacher. 1992. Effect of increasing doses of recombinant human insulin-like growth factor-I on glucose, lipid, and leucine metabolism in man. J. Clin. Endocrinol. Metab. 75:1186-1191.

13. Jacob, R. E., E. Barett, G. Plewe, K. D. Fagin, and R. S. Sherwin. 1989. Acute effects of insulin-like growth factor I on glucose and amino acid metabolism in the awake fasted rat. J. Clin. Invest. 83:1717-1723.

14. Giacca, A., R. Gupta, S. Efendic, K. Hall, A. Skottner, L. Lickely, and M. Vranic. 1990. Differential effects of IGF-I and insulin on glucoregulation and fat metabolism in depancreatized dogs. Diabetes. 39:340-347.

15. Berelowitz, M., M. Szabo, L. A. Frohman, S. Firestone, and L. Chu. 1981. Somatomedin-C mediates growth hormone negative feedback by effects on both hypothalamus and the pituitary. Science (Wash. DC). 212:1279-1281.

16. Guler, H. P., C. Schmid, J. Zapf, and E. R. Froesch. 1989. Effects of recombinant insulin-like growth factor on insulin secretion and renal function in normal human subjects. Proc. Natl. Acad. Sci. USA. 86:2868-2872.
17. Leahy, J. L., and K. M. Vandekerkhove. 1990. Insulin-like growth factor at physiological concentrations is a potent inhibitor of insulin secretion. Endocrinology. 126:1593-1598.

18. Zenobi, P. D., S. Graf, H. Ursprung, and E. R. Froesch. 1992. Effects of insulin-like growth factor-I on glucose tolerance, insulin levels, and insulin secretion. J. Clin. Invest. 89:1908-1913.

19. Zapf, J., E. Schoenle, M. Waldvogel, I. Sand, and E. R. Froesch. 1981. Effect of trypsin treatment of rat adipocytes on biological effects and binding of insulin and insulin-like growth factors: further evidence for the action of insulinlike growth factors through the insulin receptor. Eur. J. Biochem. 113:605-609.

20. Caro, J. F., J. Poulos, O. Ittoop, W. J. Pories, E. G. Flickinger, and M. K. Sinha. 1988. Insulin-like growth factor-I binding in hepatocytes from human liver, human hepatoma, and normal, regenerating, and fetal liver. J. Clin. Invest. 81:976-981.

21. McGuire, E. A. H., J. H. Helderman, J. D. Tobin, R. Andres, and M. Bergman. 1976. Effects of arterial versus venous sampling on analysis of glucose kinetics in man. J. Appl. Physiol. 55:628-634.

22. Segal, K. R., M. Van Loan, P. I. Fitzgerald, J. A. Hodgson, T. B. Van Italie. 1988. Lean body mass estimation by bioelectrical impedance analysis: a four-site cross validation study. Am. J. Clin Nutr. 47:7-14.

23. Christofides, N. D. 1982. Glucagon. In Radioimmunoassay of Gut Regulatory Peptides. S. R. Bloom, and R. G. Long, editors. W. B. Saunders Company, Philadelphia. 74-79.

24. Zapf, J., H. Walter, and E. R. Froesch. 1981. Radioimmunological determination of insulin-like growth factors I and II in normal subjects and in patients with growth disorders and extrapancreatic tumor hypoglycemia. J. Clin. Invest. 86:952-961.

25. Ciba-Geigy Limited. 1980. Geigy Scientific Charts, Volume 1, 8th edition. Basel. 62-78.

26. deBodo, R., R. Steele, N. Altszuler, A. Dunn, and J. Bishop. 1963. On the hormonal regulation of carbohydrate metabolism: studies with ${ }^{14} \mathrm{C}$ glucose. $R e$ cent Prog. Horm. Res. 19:445-488.

27. Elia, M., and G. Livesey. 1988. Theory and validity of indirect calorimetry during net lipid synthesis. Am. J. Clin. Nutr. 47:591-607.

28. Cupelli, C., A. Mari, and E. Ferrannini. 1987. Non steady state: Error analysis of Steeles model and development for glucose kinetics. Am. J. Physiol. 252:E679-E89.

29. Wilcoxon, F. 1945. Individual comparisons by ranking methods. Biomed. Bull. 1:80-83.

30. Rennert, N. J., S. Caprio, and R. S. Sherwin. 1993. Insulin-like growth factor I inhibits glucose stimulated insulin secretion but does not impair glucose metabolism in normal humans. J. Clin. Endocrinol. Metab. 76:804-806.

31. Walker, J. L., M. Ginalska-Malinowska, T. E. Romer, J. B. Pucilowska, and L. E. Underwood. 1991. Effects of the infusion of insulin-like growth factor $\mathrm{I}$ in a child with growth hormone insensitivity syndrome (Laron dwarfism). $N$. Engl. J. Med. 324:1483-1488.

32. Bar, R. S., L. C. Harrison, M. Muggeo, P. Gorden, C. R. Kahn, and J. Roth. 1979. Regulation of insulin receptors in normal and abnormal physiology in humans. Adv. Intern. Med. 24:23-52.

33. Rosetti, L., D. Smith, G. I. Shulman., D. Papachristou, and R. A. DeFronzo. 1987. Correction of hyperglycemia with phlorizin nomalizes tissue sensitivity to insulin in diabetic rats. J. Clin. Invest. 79:1510-1515.

34. Moller, N., O. Schmitz, J. O. L. Jorgensen, J. Astrup, J. F. Bak, S. E. Christensen, K. G. M. M. Alberti, and J. Weeke. 1992. Basal- and insulin-stimulated substrate metabolism in patients with active acromegaly before and after adenomectomy. J. Clin. Endocrinol. Metab. 74:1012-1019.

35. Sönksen, P. H., F. C. Greenwood, J. P. Ellis, C. Lowy, A. Rutherford, and J. D. N. Nabarro. 1967. Changes in carbohydrate tolerance in acromegaly with progress of disease and in response to treatment. J. Clin. Endocrinol. 27:14181430.

36. Gerich, J. E., M. Lorenzi, D. M. Bier, E. Tsalikian, V. Schneider, J. H. Karam, and P. Forsham. 1976. Effects of physiologic levels of glucagon and growth hormone on human carbohydrate and lipid metabolism: studies involving administration of exogenous hormone during suppression of endogenous hormone secretion with somatostatin. J. Clin. Invest. 57:8745-884.

37. Kerr, D., W. V. Tambourlane, F. Rife, and R. Sherwin. 1993. Effect of insulin-like growth factor-1 on the responses to and recognition of hypoglycemia in humans. J. Clin. Invest. 91:141-147.

38. Moller, J., J. O. L. Jorgensen, N. Moller, J. S. Christiansen, and J. Weeke. 1992. Effects of growth hormone administration on fuel oxidation and thyroid function in normal man. Metab. Clin. Exp. 41:728-731.

39. Shaw, H. F. 1991. The effects of infusion of insulin-like growth factor (IGF) I, IGF-II, and insulin on glucose and protein metabolism in fasted lambs. J. Clin. Invest. 88:614-622.

40. Schalch, D. S., H. Yuang, D. M. Ney, and R. D. DiMarchi. 1989. Infusion of human insulin-like growth factor I (IGF-I) into malnourished rats reduces hepatic IGF-I mRNA abundance. Biochem. Biophys. Res. Commun. 160:795800.

41. Clemmons, D. R., A. Smith-Banks, and L. E. Underwood. 1992. Reversal 
of diet-induced catabolism by infusion of recombinant insulin-like growth factorI in humans. J. Clin. Endocrinol. Metab. 75:234-238.

42. Karlander, S., M. Vranic, and S. Efendic. 1986. Increased glucose turnover and glucose cycling in acromegalic patients with normal glucose tolerance. Diabetologia. 29:778-783.

43. Sestoft, L. 1980. Metabolic aspects of the calorigenic effect of thyroid hormone in mammals. Clin. Endocrinol. 13:489-506.

44. Berne, R. M., N. Sperelakis, and S. R. Geiger, editors. 1979. Handbook of Physiology. Section 2: The Cardiovascular System. Volume 1. The Heart. American Physiological Society, Bethesda, MD. 775-872.

45. Zapf, J., Ch. Schmid, H. P. Guler, M. Waldvogel, C. Hauri, E. Futo, P Hossenlopp, M. Binoux, and E. R. Froesch. 1990. Regulation of binding proteins for insulin-like growth factors (IGF) in humans. J. Clin. Invest. 86:952-961.

46. Bar, R. S., D. R. Clemmons, M. Boes, W. H. Busby, B. A. Booth, B. L. Dake, and A. Sandra. 1990. Transcapillary permeability and subendothelial distribution of endothelial and amniotic fluid insulin-like growth factor binding proteins in the rat heart. Endocrinology. 127:1078-1086.

47. Bak, J. F., N. Moller, and O. Schmitz. 1991. Effects of growth hormone on fuel utilization and muscle glycogen synthase activity in normal humans $\mathrm{Am}$. J Physiol. 260:E736-E742.
48. Salomon, F., R. C. Cuneo, R. Hesp, and P. Sonksen. 1989. The effects of treatment with recombinant human growth hormone on body combosition and metabolism in adults with growth hormone deficiency. N. Engl. J. Med. 321:1797-1803.

49. Barutsch-Marrain, P. R., D. Smith, and R. A. DeFronzo. 1982. The effect of growth hormone on glucose metabolism and insulin secretion in man. J. Clin. Endocrinol. Metab. 55:973-982.

50. Rizza, R., L. W. Mandarino, and J. E. Gerich. 1982. Effects of growth hormone on insulin action in man: mechanisms of insulin resistance, impaired suppression of glucose production, and impaired stimulation of glucose utilization. Diabetes. 31:663-669.

51. Sherwin, R. S., R. G. Hendler, and P. Felig. 1983. Effect of growth hormone on oral glucose tolerance and circulating metabolic fuels in man. Diabetologia. 24:155-161.

52. Kupfer, S. R., L. E. Underwood, R. C. Baxter, and D. R. Clemmons. 1993 Enhancement of the anabolic effects of growth homeone and insulin-like growth factor I by the use of both agents simultaneously. J. Clin. Invest. 91:391-396.

53. Dahn, M. S., M. P. Lange, and L. A. Jacobs. 1988. Insulin-like growth factor-I production is inhibited in human sepsis. Arch. Surg. 123:1409-1414. 